\title{
Iwonna Michalska, Grzegorz Michalski, Wychowanie przez teatr szkolny w II Rzeczypospolitej, Warszawa 1994, ss. 126.
}

Książka została wydana przez Wyższą Szkołę Pedagogiczną Towarzystwa Wiedzy Powszechnej w Warszawie, w nakładzie 500 egzemplarzy.

Polskie środowisko historyków wychowania w poważnej swej części pozostaje w kręgu problematyki badawczej okresu międzywojennego. Do tego grona należy także zaliczyć Autorów prezentowanej pozycji.

Książka została napisana na podstawie bogatego materiału źródłowego (Dzienników Urzędowych Kuratoriów Okręgów Szkolnych, doświadczeń pracy pedagogicznej, międzywojennej literatury przedmiotu). Składa się z czterech rozdziałów. Pierszy omawia szkolny teatr tradycyjny, jego koncepcje, repertuar, znaczenie wychowawcze. Drugi poświęcony został szkolnemu teatrowi samorodnemu, kolejny - szkolnemu teatrowi kukiekkowemu, a ostatni - wspieraniu szkolnej twórczości scenicznej.

Opracowanie ma $\mathrm{z}$ założenia charakter popularyzatorski, stąd i jego ocena musi uwzględniać przyjęte przez Autorów założenie. Dokonali oni selektywnego, jasnego opisu różnorodnych poglądów na rolę teatru w edukacji, wyodrębnili ścierające się poglądy, wyartykułowali postawę krytyczną (Z. Kwieciński, A. Po- lewka, J. Cierniak) wobec fałszywego rozumienia funkcji teatru szkolnego. W tym kontekście nasuwa się czytelnikowi pytanie: co w owym teatrze ma największy walor kształcący - sama sztuka (treść), aktorstwo (osobowość), czy wspólna praca? Odpowiedź na to pytanie musi czytelnik wypracować samodzielnie szukając wsparcia w tendencjach ówczesnej pedagogiki (szczególnie Nowego Wychowania).

Zdaniem Autorów najważniejszym osiqgnięciem teatru szkolnego w okresie II Rzecz ypospolitej bylo przejście od ciasnego dydaktyzmu do uznania wartosci artystycznych; od narzucania. kierowania i instruowania do pobudzania czynne postawy mlodzieży; od moralizowania do wychowania przez życie; od nasladowania teatru zawodowego do szukania wlasnych dróg rozwoju (s. 123).

Prezentowana książka stanowi przede wszystkim przegląd, katalog pomysłów organizacyjnych, strukturalnych, treściowych, którymi posługiwali się pedagodzy okresu międzywojennego. Dla współczesnego, myślącego nauczyciela-wychowawcy jest to dobry materiał zmuszający do krytycznej refleksji nad formami i metodami własnej pracy.

Slawomir Sztobryn

Grzegorz Michalski, Zygmunt Myslakowski (1890-1971), dzialalność i twórczość pedagogiczna, Acta Universitatis Lodziensis, Folia Paedagogica et Psychologica, nr 33, Wydawnictwo Uniwersytetu Lódzkiego, Lódź 1994, ss. 152.

Dotychczasowa literatura poświęcona Zygmuntowi Mysłakowskiemu jest niezadowalająca, skromna i ograniczona tematycznie. Wyżej wymieniona rozprawa jest pierwsza, która w sposób calościowy ukazuje sylwetke tego uznanego, aczkolwiek zapomnianego pedagoga Na tle zmieniających się warunków politycznych autor przedstawia życie, działalność pedagogiczną oraz twórczość naukową uczonego. Ukazuje drogę Z. Myslakowskiego do pedagogiki: poprzez studia na Uniwersytecie
Jagiellońskim, Wiedeńskim oraz studia $\mathrm{w} \mathrm{Pa}$ ryżu.

Koncentrując się na działalności dydaktyczno-organizacyjnej uczonego autor omawia pierwsze doświadczenia pedagogiczne Mysłakowskiego w szkolnictwie średnim w Warszawie i kierownictwo Seminarium Nauczycielskim w Lublinie; pracę na Uniwersytecie Jagiellońskim zarówno w okresie II Rzeczypospolitej, jak i po wojnie; inicjatywę uczonego w organizowaniu i kierowaniu Instytutem Pedagogicznym 
w Katowicach; wkład w rozwój Poradni Wychowawczo-Leczniczej w Krakowie; prace w Naukowym Towarzystwie Pedagogicznym; współprace naukowa z Towarzystwem Uniwersytetu Robotniczego im. A. Mickiewicza w Krakowie oraz pelnienie funkcji rektora Wyższej Szkoły Pedagogicznej w Krakowie. Autor szeroko uwzględnia wkład uczonego w rozwój i organizację tych placówek.

Uwzględniając wkład Mysłakowskiego w rozwój nauk pedagogicznych przedstawia kierunki zainteresowań naukowych uczonego. Autor ukazuje jego poglądy na pedagogikę jako nauke; poglądy pedeutologiczne; koncepcję i uwarunkowania procesu wychowania, stosunek Mysłakowskiego do funkcjonujących ideałów wychowania oraz stosunek uczonego do roli podręcznika w procesie dydaktycznym.

Szeroko została omówiona społeczna i polityczna postawa Z. Mysłakowskiego.

Ewa Trojanowska

\section{Iwonna Michalska, Czasopisma Związku Nauczycielstwa Polskiego dla dzieci w okresie Drugiej Rzeczypospolitej, Wydawnictwo Uniwersytetu Lódzkiego, Lódź 1994, ss. 193.}

$\mathrm{Na}$ tle zmieniających się warunków polityczno-społecznych i oświatowych wraz $z$ uwzględnieniem tendencji $w$ pedagogice, psychologii $i$ literaturze w Polsce $w$ okresie międzywojnia autorka dokonuje analizy działalności ZNP w dziedzinie wydawnictw dla dzieci. Książka poświęcona jest pięciu czasopismom dla młodych czytelników: „Płomykowi”, „Płomyczkowi”, „Małemu Płomyczkowi”, „Szkolnej Gazetce Ściennej” oraz „Młodemu Zawodowcowi". Znajdujemy tu informacje na temat dziejów poszczególnych wydawnictw z podkreśleniem czynników mających wpływ na ich zróżnicowany charakter. Autorka nie pominęła zagadnienia czytelników, charakteryzując ich środowisko społeczne, miejsce zamieszkania oraz omawiając formy upowszechniania $i$ udostępniania pism wśród dzieci i młodzieży.

Naîwięcej miejsca poświęcono kierunkom oddziaływań wychowawczych wyżej wymienionych czasopism. Autorka prezentuje ich rolę w kształtowaniu religijnej, moralnej, społeczno-obywatelskiej, patriotycznej, intelektualnej, estetycznej i fizycznej sylwetki dziecka. W zakończeniu rozprawy ukazano recepcje związkowych czasopism oraz dokonano próby ich oceny.

(E. T.)

\section{Krzysztof Stopka, Szkoly katedralne metropolï gnieźnieńskiej w średniowieczu. Studia nad ksztaltowaniem kleru polskiego w wiekach średnich, PAU, Rozprawy Wydziału Historyczno-Filozoficznego, t. 76, Kraków 1994, ss. 274.}

Szkoły katedralne należą do najstarszych szkół, ich geneza sięga czasów schyłku starożytności. Na ziemiach polskich powstały one zapewne już w XI wieku.

Podjęte przez autora zagadnienie szkót katedralnych $w$ okresie średniowiecza było już w przeszłości w kręgu zainteresowań badaczy (A. Karbowiak, S. Chodyński, J. Skoczek; konkretnie o szkołach tego typu w metropolii gnieźnieńskiej pisali: E. Meyer, M. Rechowicz,
I. Pawlak). Jednakże żadna z prac nie stanowi całościowego opracowania zagadnienia $w$ odniesieniu do terenów ówczesnej Polski, czy nawet poszczególnych jej części.

Badania nad szkolnictwem niższym nie są łatwe, ze względu na ograniczony zasób źródeł jakie instytucje te po sobie pozostawiły. Stąd tak interesująca jest praca K. Stopki.

Praca obejmuje obszar arcybiskupstwa gnieźnieńskiego, biskupstwa poznańskiego, 